\begin{tabular}{cc|c}
\hline Tar. Bil. Der. & Tarım Bilimleri Dergisi & Journal of Agricultural Sciences \\
& $\begin{array}{c}\text { Dergi web sayfası: } \\
\text { www.agri.ankara.edu.tr/dergi }\end{array}$ & Journal homepage: \\
& www.agri.ankara.edu.tr/journal
\end{tabular}

\title{
An Evaluation of the Performance of Forced Air Cooling on Cooling Parameters in Transient Heat Transfer at Different Layers of Pomegranate
}

\author{
Mohammad-ALI BEHAEEN ${ }^{a}$, Asgar MAHMOUDI ${ }^{a}$, Seyed-FARAMARZ RANJBAR ${ }^{\mathrm{b}}$ \\ ${ }^{a}$ Tabriz University, Faculty of Agriculture, Department of Biosystem Engineering, Tabriz, IRAN \\ ${ }^{\boldsymbol{b}}$ Tabriz University, Faculty of Mechanical Engineering, Department of Mechanical Engineering, Tabriz, IRAN
}

\section{ARTICLE INFO}

Research Article

DOI: 10.15832 /ankutbd.446362

Corresponding Author: Mohammad-ALI BEHAEEN, E-mail: Ali_behaeen@yahoo.com, Tel: +98 (41) 33392779

Received: 22 July 2015, Received in Revised Form: 30 November 2015, Accepted: 11 September 2017

\begin{abstract}
The quality of horticultural products can be promoted using high techniques. One of these methods is precooling applied before storage and leads to increased shelf and storage life of the fruit. For this reason, the effect of forced air cooling was conducted to investigate the cooling rate at the center (aril), spongy tissue (peel) and leathery skin (rind) of pomegranate (Punica granatum L.). Airflow velocity as an effective factor in cooling products at three levels of $0.5,1$, and $1.3 \mathrm{~m} \mathrm{~s}^{-1}$ and temperature of $7.2^{\circ} \mathrm{C}$ was considered. Cooling parameters including lag factor and cooling coefficient were calculated from experimental data. Then, half-cooling time and seven-eighths cooling time were obtained at different layers of pomegranate. Cooling heterogeneity was analyzed at different air velocity and at different layers of pomegranate. The results showed that increase in air velocity from 0.5 to $1.3 \mathrm{~m} \mathrm{~s}^{-1}$, reduced the half-cooling time and seven-eighths cooling time. After 5000 seconds, the change of air velocity had a slight influence on decreasing temperature of different layers of pomegranate. Cooling heterogeneity at the air velocity of $0.5 \mathrm{~m} \mathrm{~s}^{-1}$ was low and then increased at the air velocity of 1 $\mathrm{m} \mathrm{s}^{-1}$. Finally, at the air velocity of $1.3 \mathrm{~m} \mathrm{~s}^{-1}$, it was declined. The overall results illustrate that the applied methodology in this research, which explains unsteady heat transfer in the cooling process, can be performed in pomegranate or similarly shaped fruits.
\end{abstract}

Keywords: Precooling; Forced air cooling; Heat transfer; Pomegranate

\section{Nar'ın Farklı Katmanlarında Geçici Isı Transferindeki Soğutma Parametreleri Üzerinde Zorlanmış Hava ile Soğutma Performansının Değerlendirilmesi}

\section{ESER BİLGí}

Araştırma Makalesi

Sorumlu Yazar: Mohammad-ALI BEHAEEN, E-posta: Ali_behaeen@yahoo.com, Tel: +98 (41) 33392779

Geliş Tarihi: 22 Temmuz 2015, Düzeltmelerin Gelişi: 30 Kasım 2015, Kabul: 11 Eylül 2017 


\section{ÖZET}

Bahçe tarımında yetiştirilen ürünlerin kalitesi, ileri teknikler kullanılarak muhafaza edilebilir. Bu yöntemlerden birisi de depolamadan önce uygulanan ön soğutma ile meyvenin raf ve depolama ömrünün uzatılmasıdır. Bu nedenle, nar (Punica granatum L.)'ın merkezinde (tanede), süngerimsi dokusunda (iç zarda) ve derisinde (kabukda) zorlanmış hava ile soğutmada, soğutma hızının etkilerini araştırmak amacıyla bu çalışma ortaya konulmuştur. Ürünlerin soğutulmasında etkili faktör olarak $0.5,1$ ve $1.3 \mathrm{~m} \mathrm{~s}^{-1}$ değerlerindeki üç farklı hava hızı ve $7.2{ }^{\circ} \mathrm{C}$ sıcaklık değeri dikkate alınmıştır. Deneysel verilerden, 1sı transferi direnç faktörü ve soğutma katsayısını içeren soğutma parametreleri hesaplanmıştır. Ayrıca, narın farklı katmanlarındaki yarı soğuma süresi ve sekizde yedi soğuma süreleri elde edilmiştir. Soğutma heterojenliği, farklı hava hızlarında ve narın farklı katmanlarında analiz edilmiştir. Sonuçlar, hava hızının $0.5 \mathrm{~m} \mathrm{~s}^{-1}$, den $1.3 \mathrm{~m} \mathrm{~s}^{-1}$ arttığında, yarı soğuma süresinin ve sekizde yedi soğutma süresinin azaldığını göstermiştir. 5000. saniyeden sonra hava hızındaki değişimin, narın farklı katmanlarındaki sıcaklığın azalması üzerinde etkisi oldukça hafif olmuştur. Soğutma heterojenliği, $0.5 \mathrm{~m} \mathrm{~s}^{-1}$ hava hızında düşük olup sonraki $1 \mathrm{~m} \mathrm{~s}^{-1}$ hava hızında artmıştır. Sonuç olarak, $1.3 \mathrm{~m}$ $\mathrm{s}^{-1}$ hava hızı uygun bulunmamıştır. Genel sonuçlar, soğutma sürecindeki kararsız 1sı iletimini açıklayan bu araştırmada uygulanan metodolojinin, nar veya benzer şekildeki meyvelerde de uygulanabileceğini göstermektedir.

Anahtar Kelimeler: Ön soğutma; Zorlanmış hava ile soğutma; Isı transferi; Nar

(C) Ankara Üniversitesi Ziraat Fakültesi

\section{Introduction}

Pomegranate (Punica granatum L.) is a plant from the family of Punicaceae (Fadavi et al 2006) and Iran is the main origin of planting this fruit. In order to supply domestic and export markets, the control of effective factors in reducing fruit quality needs to be considered. Temperature is one of the factors contributing to the rise of postharvest life in the horticultural products. Spoilage of harvested crops is proportional to their respiration rate which depends on temperature (Kader 2002). Studies have shown that, for every $10{ }^{\circ} \mathrm{C}$ reduction in temperature of the product, respiration rate diminishes by 2-4 times (Golob et al 2002). So, temperature management is crucial to maintain the quality of fruits during the postharvest period. This parameter should be managed using different techniques. Precooling is one of the most effective methods for enhancing the quality and freshness of the product, in which biochemical reactions and microbiological growth are reduced (Baird \& Gaffney 1976; Ginsburg et al 1978; Dincer \& Akaryildiz 1993; Thompson et al 1998; Brosnan \& Sun 2001). In precooling, heat is reduced in fruit and vegetable after harvest to prepare it quickly for transport and storage. In order to evaluate a precooling system, cooling rate and cooling uniformity are required. Cooling rate is measured by calculating half-cooling time; but, the temperature of cooling medium should be homogeneous (Goyette et al 1996). Precooling methods differ based on the factors such as cooling time, water contact with product, performance of energy consumption, and rate of water loss. Given the above considerations, cooling methods can be divided into the following methods: forced air cooling, room cooling, vacuum cooling, hydrocooling, evaporative cooling, and ice cooling (Brosnan \& Sun 2001).

Dennis (1984) and Hass et al (1976) stated that cooling rate with forced air cooling primarily depends on air velocity encountering the product and this is the only controllable parameter among other variables, because factors such as size, shape and physical characteristics of the product are unchangeable. Cold air temperature is a limiting factor that can not be reduced below a certain point because of frost.

Lambrinos et al (1997) found that increasing air velocity from 2 to $3.65 \mathrm{~m} \mathrm{~s}^{-1}$ decreased the cooling time up to 3 to 6 times based on the product packaging. This result was also confirmed by Emond et al (1996), who reported that seven-eighths cooling time, with increasing cooling airflow from 0.002 to $0.004 \mathrm{~m}^{3} \mathrm{~s}^{-1} \mathrm{~kg}^{-1}$ of product, was reduced by $30-40 \%$. Kumar et al (2008) reported that cold air could increase the cooling rate significantly in 
tomatoe and orange. Rapid cooling is one of the advantages of forced air cooling (Thompson et al 1998), which could change the velocity of cold air and then increase cooling rate. Investigation of heat transfer on an individual pomegranate provides more precise results on the fruit behavior in terms of cooling time. Few studies have been conducted on unsteady heat transfer on pomegranate. The objective of the present study was to evaluate the velocity of cold air as an effective factor in the rate of cooling, estimate cooling parameters, and precise determination of cooling time at the different layers of a pomegranate, namely Rabab. The results could be used as a guideline in the design of processing and cooling systems in pomegranate in order to enhance efficiency and prevent fruit loss.

\section{Material and Methods}

The pomegranate fruits (Punica granatum L. cv. Rabab) were prepared from Arsenjan city, Fars province, Iran. This kind of pomegranate is used for export. Tests were performed on three parts of the pomegranate: arils, spongy tissue (peel) and leathery skin (rind). The samples were maintained for $24 \mathrm{~h}$ in the oven at $105{ }^{\circ} \mathrm{C}$. Moisture content (w.b.) of the three parts of pomegranates on average was $81.87,79.56$, and $66.48 \%$ in arils, peel, and rind, respectively. Thickness measurements of the pomegranate layers were performed using a digital caliper. Air velocity was measured using an anemometer (Lutron-YK, 80AM, Taiwan) and then, the air velocities of $0.5,1$ and $1.3 \mathrm{~m} \mathrm{~s}^{-1}$ were selected for experiments. To perform the precooling operations, an instrument including a backward centrifugal fan (single inlet, $0.03 \times 0.01 \mathrm{~m}^{2}, 220 \mathrm{~V}$, 1400 RPM, 160W), air tunnel and cooling system was designed and built at University of Tabriz, Iran, presented in Figure 1.

In order to optimize the use of energy, a polyethylene tube with the diameter of $0.15 \mathrm{~m}$ was

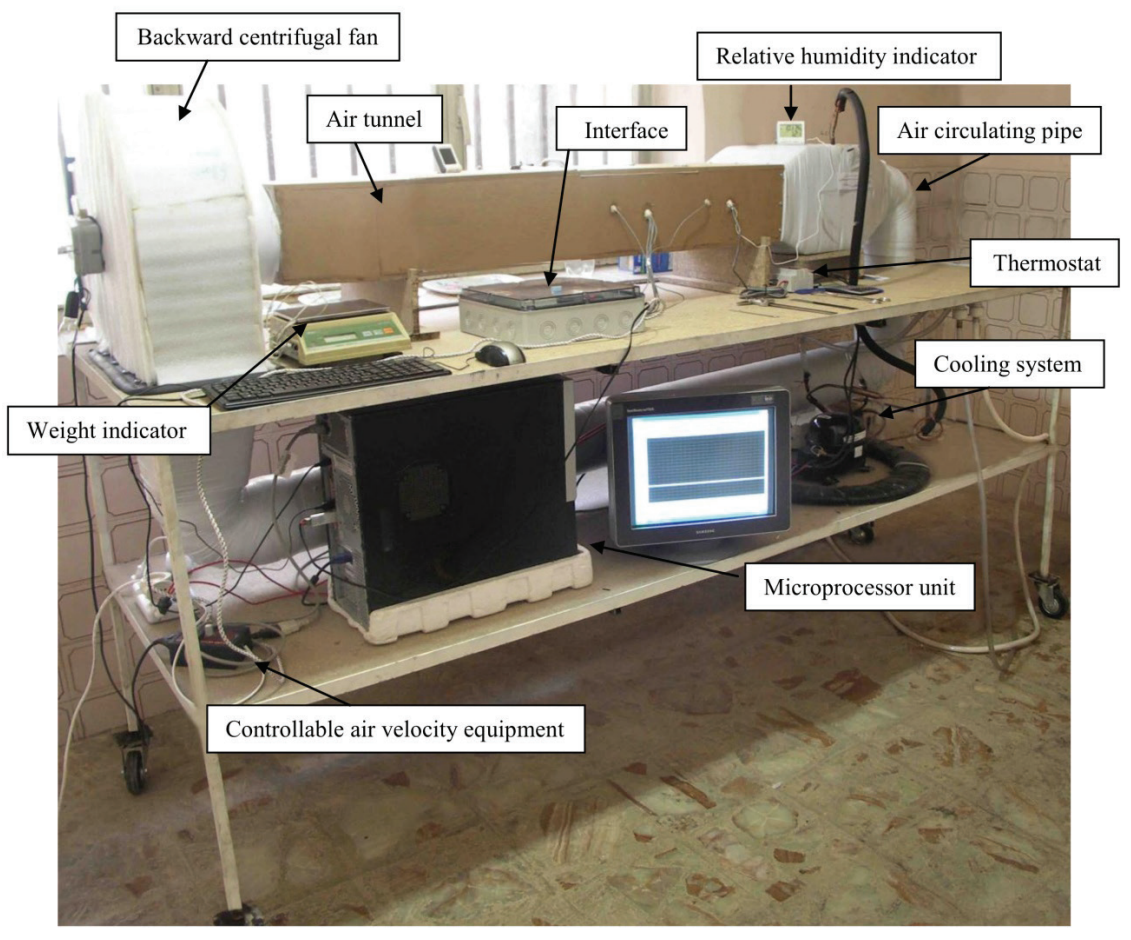

Figure 1- Experimental set up of the forced air cooling 
used for air circulation. In each experiment, $6 \mathrm{pt} 100$ sensors $(0.003 \mathrm{~m}$ length, $0.002 \mathrm{~m}$ width, and 0.0011 $\mathrm{m}$ height) were placed in different parts of a single pomegranate. Sensors were placed as follows: (a) one sensor in the center of each fruit, (b) one at 50\% of radius, (c) one in the peel, and (d) one in fruit rind. Also, two sensors recorded air temperature before and after the sample test. Placement of the entrance of the sensors was insulated. The temperatures were read and displayed per second. Accuracy of each sensor was $\pm 0.1{ }^{\circ} \mathrm{C}$. Temperatures were recorded for each sensor separately in LabVIEW software, version 2010. Before testing, the samples were placed at homogeneous temperature $\left(25{ }^{\circ} \mathrm{C}\right)$ until the temperature of all parts of the sample became almost the same. Then, the sample (single pomegranate) was placed on a pedestal in the tunnel and cooling operations was started. Cooling operations were continued until the central temperature of pomegranate reached to $10{ }^{\circ} \mathrm{C}$ and then the apparatus was turned off. The temperature was adjusted at $7.2^{\circ} \mathrm{C}$ inside the tunnel by means of a digital thermostat.

The main assumptions for conducting this experiment were as follows:

1. The test samples were homogeneous and isotropic.

2. Test conditions was conducted under unsteady state heat transfer.

3. Product temperature was the same in different parts of the fruit.

4. Thermophysical properties of the pomegranate and air temperature were constant in the tunnel $\left(\rho_{\mathrm{p}}=970 \mathrm{~kg} \mathrm{~m}^{-3}, \mathrm{k}_{\mathrm{p}}=0.52 \mathrm{~W} \mathrm{~m}^{-1}{ }^{\circ} \mathrm{C}^{-1}\right.$, and $\mathrm{C}_{\mathrm{p}, \mathrm{p}}=$ $\left.3606.07 \mathrm{~J} \mathrm{~kg}^{-1}{ }^{\circ} \mathrm{C}^{-1}\right)$.

5. Heat of respiration was ignored due to rapid cooling of the product.

In order to analyze the cooling process, calculation of the cooling parameters is essential. The dimensionless temperature inside the fruit is calculated using the product temperature at any time $(T)$, initial product temperature $\left(T_{i}\right)$, and cooling medium temperature $\left(T_{a}\right)$, (Dincer 1995).
$\theta=\frac{T-T_{a}}{T_{i}-T_{a}}$

Dimensionless temperature is expressed in the form of cooling parameters including cooling coefficient $(C)$ and lag factor $(J)$ as (Thompson et al 1998).

$\theta=J \exp (-C t)$

Cooling coefficient $(C)$ explains the ability of cooling a product; it represents the change in product temperature per unit time at any moment $(R)$ for the difference between the product temperature and cooling air $(d T)$ and its value is negative. Also, $C$ is the slope of the cooling curve (Kumar et al 2008).

$C=R / d T$

Lag factor $(J)$ implies resistance to heat transfer from the product to the surroundings (Dincer, 1995). The value of this parameter is between 1 and 2 in the center of the fruit sample. These two parameters were determined by fitting the data to the dimensionless temperature and cooling the time curve.

The cooling rates are denoted by half-cooling time $(H)$ and seven-eights cooling time $(S)$. By substituting $\theta=0.5$ for $H$ and $\theta=0.125$ for $S$ in Equation (2), $H$ and $S$ were calculated by following equation (Ngcobo et al 2013).

$H=[\ln (2 J) / C]$

$S=[\ln (8 J) / C]$

The half-cooling time is used in practical applications (Dincer 1995) and seven-eighths cooling time is used for commercial cooling operations, because this time is close to the temperature of storage and transport (Guillou 1960). Parameters $J$ and $C$ are independent from the initial product temperature and, during the cooling process, will remain constant.

Effect of different velocities on cooling uniformity and temperature distribution were 
calculated by cooling heterogeneity parameter according to the following equation (Dehghannya et al 2011).

\section{Cooling heterogeneity $=S_{d} / \bar{T}$}

Where; $S_{d}$ is standard deviation and $\bar{T}$ is mean instantaneous temperature. This index can be calculated during cooling time and at different layers of pomegranate at certain times at each point of the product.

To evaluate the effect of cooling operations on fruit weight loss, this parameter was measured. Before and after testing, each fruit was weighed by a digital scale at the accuracy of $0.01 \mathrm{~g}$. Weight loss was calculated based on the difference between initial $\left(W_{i}\right)$ and final $\left(W_{f}\right)$ weight.

Percent of weight loss $=\frac{W_{i}-W_{f}}{W_{i}} \times 100$
Finally, least significant difference (LSD) test was used to test differences between means ( $p=$ 0.05).

\section{Results and Discussion}

\subsection{Cooling rate}

Cooling rate and cooling parameters of the pomegranate layers are shown at the air velocities of $0.5,1$ and $1.3 \mathrm{~m} \mathrm{~s}^{-1}$ in Table $1(\mathrm{a}, \mathrm{b}, \mathrm{c})$.

At any air velocity, with increasing the radius of pomegranate from the center to the rind (outer shell), the lag factor decreased and cooling coefficient enhanced. Finally, half-cooling times and seven-eights cooling times decreased. Change of the lag factor depends on shape, size, and thermal characteristics of the product. Also, a lag factor greater than 1 causes an internal resistance to heat

Table 1- Cooling parameters in different layers of pomegranate $(a, b, c)$

\begin{tabular}{ccccccc}
\hline $\begin{array}{c}\text { Placement of } \\
\text { sensors }\end{array}$ & $J$ & $C\left(s^{-1}\right)$ & $H(s)$ & $S(s)$ & $R^{2}$ & ${ }^{*} E(\%)$ \\
\hline Center & 1.1749 & 0.00028 & 3051.18 & 8002.23 & 0.9936 & 3.27 \\
$50 \%$ of radius & 1.0069 & 0.00031 & 2258.14 & 6730.06 & 0.9996 & 0.88 \\
Peel & 0.9959 & 0.00033 & 2087.10 & 6288.89 & 0.9994 & 1.40 \\
Rind & 0.8685 & 0.00032 & 1725.50 & 6057.67 & 0.9964 & 2.99 \\
\hline \multicolumn{7}{c}{$\mathrm{V}=1 \mathrm{~m} \mathrm{~s}^{-1}(\mathrm{~b})$} \\
\hline $\begin{array}{c}\text { Placement of } \\
\text { sensors }\end{array}$ & $J$ & $C\left(s^{-1}\right)$ & $H(s)$ & $S(s)$ & $R^{2}$ & ${ }^{*} E(\%)$ \\
\hline Center & 1.2033 & 0.00031 & 2832.95 & 7304.87 & 0.9955 & 3.35 \\
$50 \%$ of radius & 0.9761 & 0.00033 & 2027.14 & 6228.03 & 0.9994 & 2.06 \\
Peel & 0.9461 & 0.00036 & 1771.50 & 5622.32 & 0.9991 & 2.09 \\
Rind & 0.9450 & 0.00043 & 1480.41 & 4704.35 & 0.9975 & 0.95 \\
\hline \multicolumn{7}{c}{$\mathrm{V}=1.3 \mathrm{~m} \mathrm{~s}^{-1}(\mathrm{c})$} \\
\hline $\begin{array}{c}\text { Placement of } \\
\text { sensors }\end{array}$ & $J$ & $C\left(s^{-1}\right)$ & $H(s)$ & $S(s)$ & $R^{2}$ & ${ }^{*} E(\%)$ \\
\hline Center & 1.1618 & 0.00031 & 2719.73 & 7191.65 & 0.9936 & 3.34 \\
$50 \%$ of radius & 1.0182 & 0.00041 & 1734.59 & 5115.80 & 0.9989 & 1.95 \\
Peel & 0.9135 & 0.00041 & 1469.94 & 4851.15 & 0.9971 & 3.02 \\
Rind & 1.0619 & 0.00053 & 1421.15 & 4036.79 & 0.9913 & 6.47 \\
\hline
\end{tabular}

*, maximum difference between the experimental and regression data 
transfer from the product to airflow (Dincer 1995). As a result, in the center of product and the radius close to the center, the heat transfer was conducted more slowly than the other layers (Table 1). Cooling coefficient $(C)$ and cooling rate were enhanced with increasing the air velocity. Increasing in air velocity from 0.5 to $1.3 \mathrm{~m} \mathrm{~s}^{-1}$, reduced the half-cooling time and seven-eights cooling time up to $10.86 \%$ and $10.13 \%$ in the center (aril) and by $17.64 \%$ and $33.36 \%$ in the outer layer (rind), respectively. These were consistent with the findings by Dincer (1995) and Castro et al (2005). It should be also noted that shape and size were the factors that could affect rate of cooling. The experiments conducted by Castro et al (2005) showed that increasing the air velocity led to increasing of cooling rate. These experiments were carried out by the polymer spheres which were similar in shape, size, and thermal properties. Considering the fact that the pomegranates which were tested, were not exactly the same in terms of shape, cooling parameters could be partially affected $(J \& C)$. The results corresponded to those by Dincer (1995) who stated that shape, size, and thermal properties affected the lag factor of product. Cooling curves (cooling models) at different layers of pomegranate are shown in Figure 2.

The mean air and product temperatures were 7.2 and $22.2^{\circ} \mathrm{C}$, respectively. With approaching the end of the cooling process, the slope of the curves decreased in all the curves. In other words, at the end of the cooling time, the reduction of temperature was slower due to the lower temperature difference between the layers of pomegranate and cold air temperature. Dimensionless temperature, $\theta$, of less than 0.2 had a slight effect on the cooling rate at different velocities in the center and $50 \%$ of radius of the pomegranate. However, the cooling rate had a small effect on the spongy tissue (peel) and the outer shell (rind) at the dimensionless temperature of less than 0.1. After 5000 seconds, the changes of air velocity had a small effect on reducing the temperature of the different layers of the center to the rind of the fruit. These results were compatible with the reports by other researchers (Kumar et al 2008). The value of the lag factor of greater than 1 occurred in the center $(1.1749,1.2033$, and 1.1618), which represented an internal resistance to heat transfer against the airflow. At the velocity of 1.3 $\mathrm{m} \mathrm{s}^{-1}$ and in the outer layer (rind), the lag factor increased (1.0619), which was probably due to partial differences in the thermophysical properties of the product layers. However, with increasing the cooling coefficient up to 0.00053 , the ability of heat transfer at the rind layer improved; therefore, the half-cooling time and seven-eights cooling time reduced. Cooling of the fruit started with time delay of the initial cooling time (0-500 seconds) and in the center of the product, which led the beginning of the cooling curve to become flat. The reason for this subject may be the distance from the center of the pomegranate to the cold air in the cooling time of the product. Lindsay et al (1983) findings showed that the center of potatoe, which was at the top layers relative to the cold air, was cooled with a time lag.

Seven-eighths cooling time $(S)$ is a part of the half-cooling time $(H)$ (Henry \& Bennett 1973). The range of $S$ was 2.5-3.5 $\mathrm{H}$ in this study (Table 2).

In the systems where cooling rate is rapid, temperature changes in the product (center) are slower than the surface temperature changes in rind (outer shell). In such cases, the limiting factor is heat conduction from the center to surface of the product. This state alters the relative difference between $S$ and $H$.

Table 2- The ratio of $S / H$ in different parts of pomegranate

\begin{tabular}{ccccc}
\hline Airflow velocity $\left(\mathrm{m} \mathrm{s}^{-1}\right)$ & Center & $50 \%$ of radius & Peel & Rind \\
\hline 0.5 & $2.62^{\mathrm{a}} \pm 0.02^{*}$ & $2.98^{\mathrm{a}} \pm 0.13$ & $3.01^{\mathrm{b}} \pm 0.04$ & $3.51^{\mathrm{a}} \pm 0.15$ \\
1 & $2.58^{\mathrm{a}} \pm 0.03$ & $3.07^{\mathrm{a}} \pm 0.11$ & $3.17^{\mathrm{ab}} \pm 0.24$ & $3.18^{\mathrm{b}} \pm 0.18$ \\
1.3 & $2.64^{\mathrm{a}} \pm 0.06$ & $2.95^{\mathrm{a}} \pm 0.09$ & $3.30^{\mathrm{a}} \pm 0.13$ & $2.84^{\mathrm{c}} \pm 0.14$
\end{tabular}

*, mean $( \pm \mathrm{SD})$. Values in the same column with the same letter(s) are not significantly different, using LSD test at an alpha level of $5 \%$ 




- Measured - - - Predicted
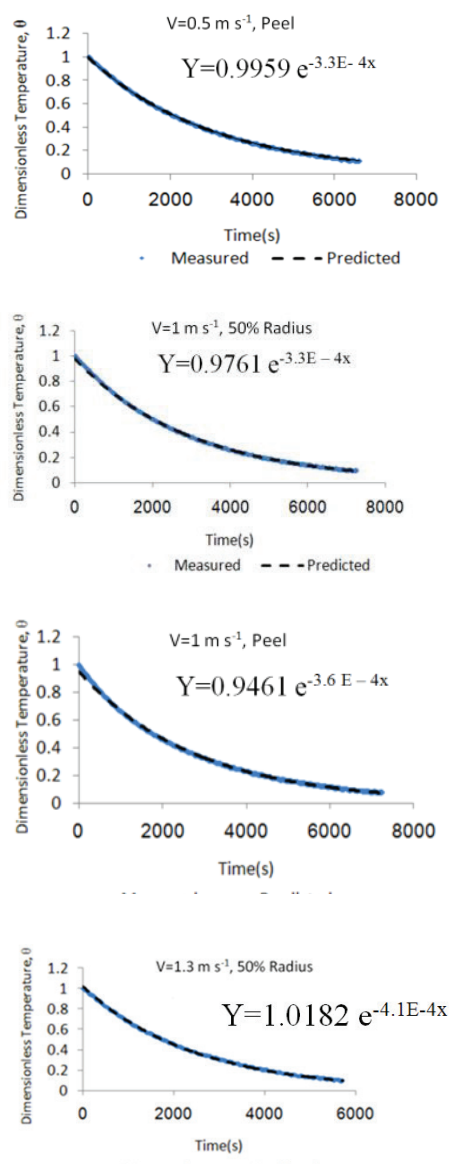

Measured - - - Predicted

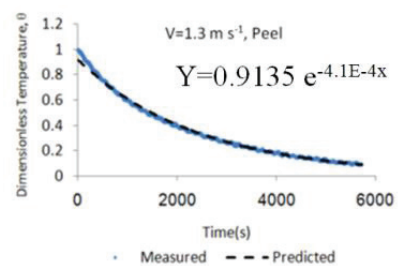

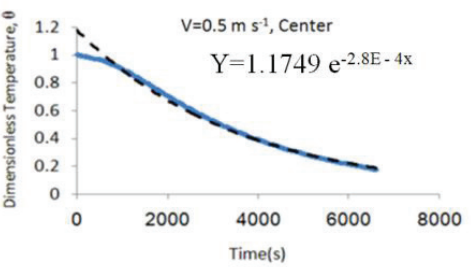

Measured - - - Predicted
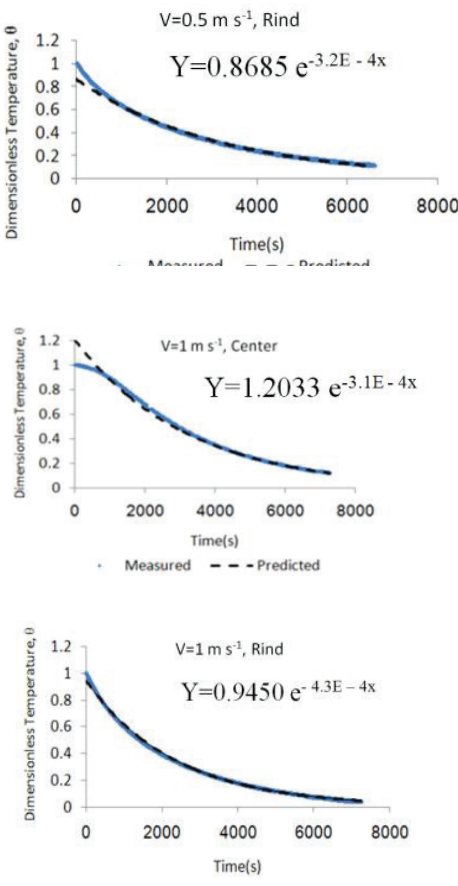

- Measured - - - Predicted
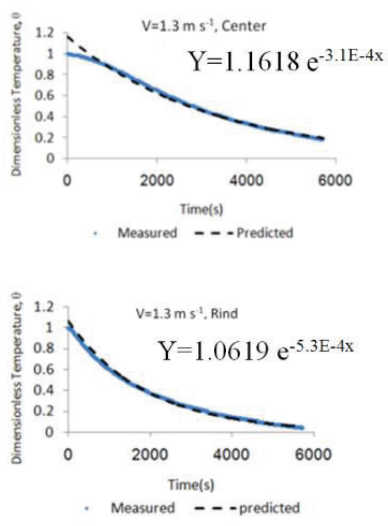

Figure 2- Cooling curves (experimental and regression) in different parts of pomegranate 


\subsection{Cooling heterogeneity}

According to Figure 3, cooling heterogeneity was low at different layers at the air velocity of $0.5 \mathrm{~m} \mathrm{~s}^{-1}$. Then, with increasing air velocity to $1 \mathrm{~m} \mathrm{~s}^{-1}$, it was increased and again decreased at $1.3 \mathrm{~m} \mathrm{~s}^{-1}$.

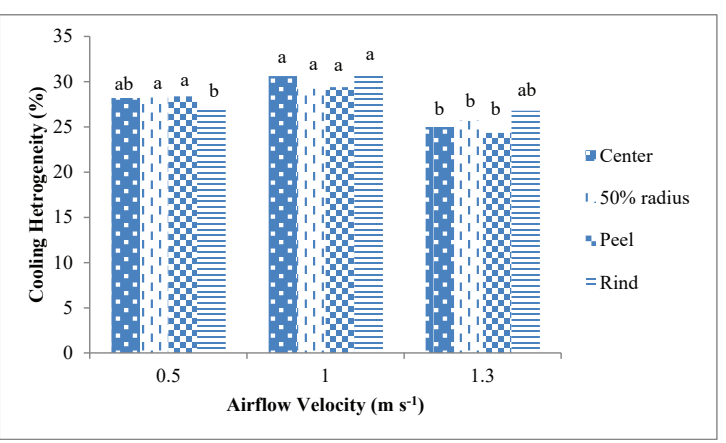

Figure 3- Cooling heterogeneity at three levels of airflow velocity in different parts of pomegranate (values with the same letter(s) are not significantly different, using LSD test at an alpha level of 5\%)

Castro et al (2005) conducted an experiment on the spheres of polymer and reported that heterogeneity at the air velocity of $0.03 \mathrm{~m} \mathrm{~s}^{-1}$ was 0.505 . This value was less than the air velocity of $0.128 \mathrm{~m} \mathrm{~s}^{-1}$ with the cooling heterogeneity of 0.534 and then, by increasing the air velocity to $1.043, \mathrm{~m}$ $\mathrm{s}^{-1}$ the cooling heterogeneity was reduced (0.409) due to the influence of gravity at lower air velocity. However, the half-cooling time at the airflow velocity of $0.03 \mathrm{~m} \mathrm{~s}^{-1}$ was 2.6 times higher than the time for the airflow velocity of $0.128 \mathrm{~m} \mathrm{~s}^{-1}$. Castro et al (2004) also reported that the airflow velocity of $0.024 \mathrm{~m} \mathrm{~s}^{-1}$ in contact with plastic sphere created more uniform distribution of air than the air velocity of $0.111 \mathrm{~m} \mathrm{~s}^{-1}$. They mentioned that the probable reason can be the natural convection effect. Results of the present research showed an inversion in the air velocity of 0.5 to $1 \mathrm{~m} \mathrm{~s}^{-1}$. It was expected that heterogeneity would reduce with increasing air velocity, which was observed from the air velocity 1 to $1.3 \mathrm{~m} \mathrm{~s}^{-1}$. The lowest heterogeneity obtained at the air velocity of $1.3 \mathrm{~m} \mathrm{~s}^{-1}$ that showed the temperature distribution at the layers of pomegranate was more uniform than the other velocities. Based on Figure 2, after the cooling period of time (5000 seconds), approximately all layers of the pomegranate got the same temperature; so, the heterogeneity of the various layers reduced. Results of the experiments by Dehghanniya et al (2011) also indicated that the column of the layers of plastic spheres became almost isothermal after a certain period of time and the cooling heterogeneity of layers decreased.

\subsection{Weight loss of pomegranate}

Based on the experimental data, the influence of airflow velocity on the weight loss of pomegranate fruit was low (Table 3). Therefore, this parameter paid no attention to the cooling calculations.

\section{Conclusions}

Cooling efficiency is generally evaluated based on two parameters: (1) rapid cooling (by reduction in half and seven-eights cooling time) and (2) cooling uniformity (by reduction in cooling heterogeneity). Based on these two parameters:

1- The trend of cooling curves against time was exponential for all the layers of pomegranate.

2- The half and seven-eights cooling time were reduced considerably at all layers of pomegranate

Table 3- Weight loss at different airflow velocity

\begin{tabular}{cccc}
\hline $\begin{array}{c}\text { Airflow velocity } \\
\left(\mathrm{m} \mathrm{s}^{-1}\right)\end{array}$ & $\begin{array}{c}\text { Initial weight } \\
(\mathrm{g})\end{array}$ & $\begin{array}{c}\text { Final weight } \\
(\mathrm{g})\end{array}$ & $\begin{array}{c}\text { Percent of weight } \\
\text { loss }\end{array}$ \\
\hline 0.5 & $334.13^{\mathrm{b}} \pm 3.52^{*}$ & $333.39^{\mathrm{b}} \pm 3.19$ & $0.22^{\mathrm{a}}$ \\
1 & $347.46^{\mathrm{ab}} \pm 2.93$ & $346.74^{\mathrm{ab}} \pm 3.15$ & $0.21^{\mathrm{a}}$ \\
1.3 & $355.47^{\mathrm{a}} \pm 4.07$ & $354.90^{\mathrm{a}} \pm 3.99$ & $0.16^{\mathrm{a}}$ \\
\hline
\end{tabular}

*, mean $( \pm \mathrm{SD})$. Values in the same column with the same letter(s) are not significantly different, using LSD test at an alpha level of 5\% 
with increasing airflow velocity in the range of 0.5 to $1.3 \mathrm{~m} \mathrm{~s}^{-1}$, which proved the direct efficacy of airflow velocity on cooling rate. This effect may be due to the change in the heat transfer coefficient.

3- The lowest value of cooling heterogeneity was at the highest air velocity $\left(1.3 \mathrm{~m} \mathrm{~s}^{-1}\right)$ that made temperature distribution more uniform.

4- After a specific time (5000 seconds), the influence of airflow velocity was low on cooling rate. Thus, the consumption of energy could be reduced by decreasing the airflow velocity in commercial applications.

5- The results showed that the applied method in this experiment could be used for pomegranate or similarly shaped fruits, which clearly and without complex calculations could explain the unsteady heat transfer in the cooling process.

6- The air velocity of $1.3 \mathrm{~m} \mathrm{~s}^{-1}$ is recommended for forced air precooling operations at different layers of pomegranate.

\begin{tabular}{|ll|}
\hline Abbreviations and Symbols \\
\hline$C$ & Cooling coefficient, $\mathrm{s}^{-1}$ \\
$H$ & Half-cooling time, $\mathrm{s}$ \\
$J$ & Lag factor, dimensionless \\
$S$ & Seven-eights cooling time, $\mathrm{s}$ \\
$\rho_{p}$ & Product density $\left(\mathrm{kg} \mathrm{m}^{-3}\right)$ \\
$k_{p}$ & Thermal conductivity of product $\left(\mathrm{W} \mathrm{m}^{-1}{ }^{\circ} \mathrm{C}^{-1}\right)$ \\
$C_{p, p}$ & Specific heat capacity of product $\left(\mathrm{J} \mathrm{kg}^{-1} \mathrm{C}^{-1}\right)$ \\
$T$ & Product temperature at any time, ${ }^{\circ} \mathrm{C}$ \\
$T_{a}$ & Cooling medium temperature, ${ }^{\circ} \mathrm{C}$ \\
$T_{i}$ & Initial product temperature, ${ }^{\circ} \mathrm{C}$ \\
$\bar{T}$ & Mean instantaneous temperature, ${ }^{\circ} \mathrm{C}$ \\
\hline
\end{tabular}

\section{References}

Baird C D \& Gaffney J J (1976). A numerical procedure for calculating heat transfer in bulk loads of fruits or vegetables. ASHRAE Transactions 82(2): 525-540

Brosnan T \& Sun D (2001). Precooling techniques and applications for horticultural products-a review. International Journal of Refrigeration 32: 154-170
Castro L R, Vigneault C \& Cortez L A B (2004). Effect of container opening area on air distribution during precooling of horticultural produce. Transactions of the ASAE 47(6): 2033-2038

Castro L R, Vigneault C \& Cortez L A B (2005). Cooling performance of horticultural produce in containers with peripheral openings. Postharvest Biology and Technology 38: 254-261

Dehghannya J, Ngadi M \&Vigneault C (2011). Mathematical modeling of airflow and heat transfer during forced convection cooling of produce considering various package vent areas. Food Control 22: 1393-1399

Dennis C (1984). Effect of storage and distribution conditions on the quality of vegetables. Acta Horticulturae 163: 85-104

Dincer I (1995). Airflow precooling of individual grapes. Journal of Food Engineering 26: 243-249

Dincer I \& Akaryildiz E (1993). Transient temperature distributions within spherical products with internal heat generation and transpiration. International Journal of Heat and Mass Transfer 36: 1998-2003

Emond J P, Mercier F, Sadfa S O, Bourre M \& Gakwaya A (1996). Study of parameters affecting cooling rate and temperature distribution in forced air precooling of strawberry. Transactions of the ASAE 39(6): 21852191

Fadavi A, Barzegar M \& Azizi M H (2006). Determination of fatty acids and total lipid content in oilseed of 25 pomegranates varities grown in Iran. Journal of Food Composition Analysis 19: 676-680

Ginsburg L, Combrink J C \& Truter A B (1978). Long and short term storage of table grapes. International Journal of Refrigeration 1(3): 137-142

Golob P, Farrell G \& Orchard G E (2002). Crop Postharvest Science and Technology, Principles and Practices. Volume 1. Blackwell Publishing Company, Oxford, UK, pp. 554

Goyette B, Vigneault C, Panneton B \& Raghavan G S V (1996). Method to evaluate the average temperature at the surface of horticultural crop. Canadian Agricultural Enigineering 38(4): 291-295

Guillou R (1960). Forced air fruit cooling Transactions of the ASAE 3(2): 16-18

Hass E, Felsenstein G, Shitzer A \& Manor G (1976). Factors affecting resistance to airflow through packed fresh fruit. ASHRAE Transactions 82(2): 548-554 
Henry F E \& Bennett A H (1973). Hydraircooling vegetables products in unit loads. Transactions of the ASAE 16(40): 731-739

Kader AA (2002). Posthaevest technology of horticultural crops. Cooperative Extension of University of California, Division of Agricultural and Natural Resources, University of California, Davis, CA, Publication No. 3311

Kumar R, Kumar A \& Murthy U N (2008). Heat transfer during forced air precooling of perishable food products. Biosystems Engineering 99: 228-233

Lambrinos G, Assimaki H, Manolopoulou H, Sfakiotakis E \& Porlimgis J (1997). Air precooling and hydrocooling of Hayward Kiwifruit. Acta Horticulturae 444: 561-566
Lindsay R T, Neale M A \& Messer H J M (1983). Ventilation rates for positive ventilation of vegetables in bulk bins. Journal of Agricultural Engineering Research 28(1): 33-44

Ngcobo M E K, Delele M A, Opera U L \& Meyer C J (2013). Performance of multi-packaging for table grapes based on airflow, cooling rates and fruit quality. Journal of Food Engineering 116: 613-621

Thompson J F, Mitchel F G, Rumsey T R, Kasmire R F \& Crisosto C H (1998). Commercial cooling of fruits, vegetables, and flowers. University of California, Agriculture and Natural Resources, Davis, DANR Publication 21567 